\title{
「センサベースト・インダストリアルロボット」 特集にあたって
}

本年の IEEE Robotics and Automation では 'Is U.S. robotics research any benefit to U.S. industry'といらパネルディスカッションが設けられ, ロボテ ィクス研究と産業界の恢離が議論になった。このパネル に最初に登場した GMF の G. Rutledge 氏の 'I'm representative of the real world.'といら言葉には, 産業 界から研究の現場に対して, 現実の問題をとらえて研究 を進めて欲しいとの強い思いが込められていた。 また， IEEE R\&A でもあえてこのパネルを設定し，多くの参 加者を集め活発な議論が交わされたのも，口ボティクス 研究に関して, 遠い将来の幻想だけでは世の中に受け入 れられなくなり，ェンジニアリングとしてロボットの活 躍場面で実際の問題点がどこにあるかを認識すべきであ るとの反省が現れてきたものであろら．

知能ロボットの課題として, センサ情報処理, 認識等 があげられており精力的に研究が行われている. 一方, 産業用ロボットの定義によれば，「センサ付きロボッ ト」に知能ロボット」とされており研究と夷用の差はき わめて大きいといえる.このキャップを事例に即して考 えてみたいといらのが本特集の主旨である.

本特集を展望する意味で最初に，(株)安川電機製作所 の久良修郭・田中雅人両氏には，ロボットメーカの立場 からロボット適用領域を払大するためのロボット用セン サシステムに対する要求条件をビジョンシステムおよび カセンシングシステム開発の具体例を挙げて論じていた だいた.

次いで, ロボットの応用分野として「バリとり作業」 「組立作業」「溶接作業」「柔軟物操作作業」を取り上げ, それぞれ具体的事例をべースに作業におけるセンシング と作業プロセスをご紹介いただいた．「バリとり作業」 に関しては，まず(株)明電舎の山口雅行氏にバリ取りシ ステムとしての構成要素技術と研削負荷に適応した加工 送り速度制御方式についてご紹介いただいた. 次いで, 日立建機(株)の柏木邦雄氏には 6 軸力センサを用いた仮
想コンプライアンス制御方式と制御モードにおける，作 業目的および対象に応じたパラメタの設定を論じていた だいた、「組立作業」に関しては，まず電総研の長谷川勉 氏にモデルとスキルを用いた作業計画実行システムにつ いて論じていただいた。ここで述べられているよらに， 作業をシステム的に構築することがロボット研究の大 きな課題の一つである. 次いで, 日本 IBM(株)の石川 浩・木田裕弥両氏には 6 軸力センサを用いたコンプライ アンス制御によるコネクタ挿入作業のプロセスと方略を 事例に即してご紹介いただいた．さらに，ソニー(株)の 黒木義博・長田康行氏には組立プロセスにおける視覚の 位置決めへの適用に関してニーズ，シーズ両面から課題 を整理していただくとともに，事例をご紹介いただいた. 「溶接作業」に関しては，まず NTT アドバンステクノ ロジ(株)の清水湧一氏にアーク溶接におけるセンサ方式 および倣い制御方式に関して広くご紹介いただいた．次 いで，(株)日立製作所の平井明・柴田信雄・赤津利雄・ 川崎恭一の四氏にはレーザ視覚センサ処理プロセスを中 心に倣い溶接ロボットシステムにつきご紹介いただい た.「柔軟物操作作業」は必ずしもロボットが得意な分 野でなく，布等のハンドリングがようやく試みられ始め た現状を踏まえて, 繊高研の小野栄一氏に歴史的にかつ 幅広く課題と技術的対応についてご紹介いただいた。

研究所紹介では, Stanford Research Institute (SRI) の Prasanna Mulgonkar·David Nitzan 両氏に, SRI におけるロボット研究の概要と特にビジョンの応用例を ご紹介いただいた。

本来, ロボットはこれまでの目的主導型の専用機械に 対して, 目的にフレキシブルに対応できる汎用機械とし て位置づけることができる，ロボットにより広範な分野 の作業をさせるには運動制御, 七ンサ処理の上位に位直 する作業の規定, 七ンサ入力をも含めた状態量・操作量 のシステマティックな規定・枠組みに関する研究の進展 が望まれる.

（水川 真） 